\title{
Penyuluhan Kesehatan Bidang Forensik dengan Topik Visum et Repertum di UPT Puskesmas Medan Denai Tanggal 21 November 2019
}

\author{
Asan Petrus, Erwin Sembiring, Oktaviana Malau, Rakmatsyah, Adriyan Rival, Hendra \\ Aprialdi
}

Departemen Kedokteran Forensik dan Studi Medikolegal, Fakultas Kedokteran Universitas

Sumatera Utara

\begin{abstract}
ABSTRAK
Visum et repertum sebagi salah satu alat bukti yang syah di pengadilan yang berperan dalam proses pembuktian suatu perkara, sehingga tindak pidana yang terjadi semakin jelas maka visum et repertum yang dibuat berdasarkan hasil pemeriksaan dokter harus berkualitas baik .dengan demikian fungsi dan peran visum et repertum itu sendiri terpenuhi, namun berdasarkan beberapa penelitian terhadap visum et repertum kualitasnya belum baik. Upaya untuk merealisasikan visum et repertum yang berkualitas baik menurut hemat kami perlu dilakukan penyuluhan terkait dengan bentuk visum et repertum yang baik bagi tenaga medis yang langsung membuat visum et repertum itu sendiri.
\end{abstract}

Kelompok yang menjadi target sasaran penyuluhan adalah dokter-dokter umum yang bekerja di UPT PUSKESMAS Medan Denai Kota Medan untuk meningkatkan pemahaman dalam membuat visum et repertum yang berkualitas baik.

Metode pelaksanaan kegiatan dengan metode ceramah dan tanya jawab, lalu akan dilakukan evaluasi keberhasilan dengan pre test sebelum penyuluhan dan post tes setelah penyuluhan..

Kata kunci: Pengabdian masyarakat; Visum et repentum

\section{PENDAHULUAN}

Dewasa ini banyak sekali kita mendengar bahkan melihat sendiri peristiwa-peristiwa (kasus-kasus) kejahatan yang tidak hanya melibatkan harta benda tetapi nyawa seseorang. Dalam perjalanan menelusuri kasus-kasus tersebut, pihak kepolisian melakukan penyelidikan hingga kemudian berakhir di peradilan. Dalam proses penyidikan kasus yang melibatkan nyawa seseorang umumnya penyidik meminta bantuan dari ahli misalnya dokter dalam bentuk keterangan yang disebut visum et repertum.

Bantuan dokter kepada kalangan hukum (penyidik, pengacara, hakim) mutlak diperlukan dalam hal ini adalah pemeriksaan korban untuk pembuatan Visum et Repertum (VeR) atau lebih sering disingkat 'visum' saja. Kerjasama yang baik antara kepolisian/penyidik dengan dokter /ahli forensic sudah terbangun sejak lama dan terus bekerja sama saling bahu membahu untuk menegakkan keadilan baik bagi korban maupun tersangka. Visum adalah jamak dari Visa, yang berarti dilihat dan repertum adalah jamak dari Repere yang berarti ditemukan atau didapati, sehingga terjemahan langsung dari VeR adalah yang dilihat dan ditemukan.

Dari rumah sakit pemerintah maupun swasta sampai ke puskesmas, setiap bulan ada ratusan pemeriksaan yang harus dilakukan dokter untuk membuat visum yang diminta 
oleh penyidik, yang paling banyak adalah visum untuk luka /visum perlukaan karena perkelahian, penganiayaan, dan kecelakaan lalu lintas, selanjutnya visum untuk pelanggaran kesusilaan atau perkosaan, kemudian diikuti visum jenazah.

Pembuatan Visum et repertum sebagai bentuk laporan hasil pemeriksaan korban tindak pidana, baik korban hidup maupun korban mati, merupakan salah satu pelayanan yang diberikan oleh dokter umum maupun kedokteran forensik/ahli forensic yang dapat membantu penegak hukum dalam menegakkan keadilan. Visum et repertum adalah keterangan tertulis dari seorang dokter umum (dalam kapasitasnya sebagai ahli) atau dokter ahli forensik atas permintaan resmi dari penegak hukum yang berwenang tentang apa yang dilihat dan ditemukan pada objek yang diperiksanya (tubuh korban baik hidup maupun mati atau bagian dari tubuh manusia atau diduga bagian dari tubuh manusia) dengan mengingat sumpah atau janji ketika menerima jabatan. Visum et repertum yang dimaksud merupakan salah satu alat bukti di peradilan yang jika dalam pembuatannya tidak benar atau kurang berkualitas maka peranan visum dalam proses pembuktian suatu perkara pidana terhadap kesehatan dan jiwa manusia tidak tercapai, yang berlanjut seringnya hakim perkara pidana sulit mengambil keputusan sidang tersebut.

Berdasarkan pada Peraturan Konsil Kedokteran Indonesia nomor 11 tahun 2012 tentang Standar Kompetensi Dokter Indonesia (SKDI) halaman 29 bagian permasalahan yang terkait profesi dokter poin 28 yang menyatakan dokter menolak dan /atau tdak membuat visum et repertum sesuai dengan standar keilmuan yang seharusnya wajib dikerjakan. Peraturan ini merupakan peedback gambaran umum mengenai permasalahan pelayanan kesehatan di lapangan khususnya dalam pelayanan untuk membantu pasien dalam upaya penegakan hukum terkait dengan tindak pidana yang dialaminya.disamping itu juga menurut Herkutanto dalam penelitiannya tahun 1999-2000 terhadap 977 VeR korban hidup di 38 rumah sakit di Jakarta tampak bahwa sebagian besar VeR di berbagai RS masih berkualitas rendah (Herkutanto, 2005).

Penelitian lain oleh Fadlan Tri Ramadhan, Dedi Afandi, Laode Burhanuddin Mursali yang meneliti kualitas visum di RSUD DR.RM.PRATOMO Bagan siapi-api periode 2009-2013 menunjukkan hasil kualitas visum et repertum yang buruk.

\section{RUMUSAN MASALAH}

Dokter umum yang saat ini bekerja di UPT PUSKESMAS Medan Denai adalah dokter yang menangani pertama sekali kasus korban tindak pidana sehingga merekalah yang membuat visum untuk disampaikan kepada penyidik yang memintanya, kualitas visum yang dibuat sangat menentukan sejauhmana fungsi dan peran visum et repertum yaitu sebagai alat bukti dan berperan dalam proses pembuktian suatu perkara pidana. Berdasarkan latar belakang diatas, dan temuan pada penelitian sebelumnya maka permasalahan yang dapat dirumuskan adalah pemahaman dan Keterampilan dalam membuat visum et repertum kualitas baik masih kurang; dan perlunya sosialisasi dalam bentuk penyuluhan dengan topik visum et repertum.

\section{TARGET DAN HASIL}

Target dari penelitian ini adalah untuk memberikan pengetahuan tentang undangundang yang terkait dengan peran dokter umum di UPT PUSKESMAS Medan Denai yang sering kali diminta untuk membantu penyidik dalam membantu penyidikan terkait dengan kasus tindak pidana yang dialami oleh pasien/korban semakin lebih baik serta meningkatkan keterampilan dokter umum di UPT PUSKESMAS Medan Denai yang diminta untuk melakukan pemeriksaan 
kedokteran serta membuat laporan dalam bentuk visum et repertum dengan kualitas baik.

Luaran yang diharapkan adalah agar para dokter umum di UPT PUSKESMAS Medan Denai mampu memahami undang undang yang terkait dengan perannya dalam membantu penyidik dan menerapkannya dalam kegiatan sehari-hari terutama dalam pembuatan visum et repertum maupun ketika diminta sebagai saksi ahli di sidang pengadilan. ,visum et repertum yang dibuat oleh dokter umum yang bekerja di UPT PUSKESMAS Medan Denai berkualitas baik, artikel ini dapat termuat di media massa/ surat kabar nasional dan artikel pengabdian ini dipublikasikan di jurnal nasional.

\section{METODE}

Kegiatan pengabdian masyarakat di UPT PUSKESMAS Medan Denai dilaksanakan pada tanggal 8 November 2019, kegiatan yang dilaksanakan meliputi penyuluhan kesehatan bidang forensic dengan topik Visum et Repertum. Kegiatan penyuluhan kesehatan bidang forensic dengan topik Visum et Repertum ini dilakukan dengan tahapan persiapan kegiatan kegiatan, kegiata penyuluhan, dan penutupan.

Pada persiapan kegiatan, peneliti melakukan survei lokasi pengabdian masyarakat yaitu pada UPT PUSKESMAS Medan Denai, lalu meminta ijin untuk melaksanakan kegiatan pengabdian masyarakat kepada Kepala UPT PUSKESMAS Medan Denai, melakukan pengurusan administrasi (surat menyurat) mempersiapkan alat dan bahan serta akomodasi, dan mempersiapkan tempat penyuluhan yaitu Aula UPT PUSKESMAS Medan Denai. Persiapan kegiatan ii dilakukan selama 1 minggu pada minggu pertama

Kegiatan penyuluhan meliputi pendahuluan, oleh moderator, yaitu memperkenalkan diri tim penyuluhan dengan para peserta/sasaran kegiatan. Lalu diikuti oleh pembukaan oleh kepala UPT PUSKESMAS Medan Denai. Selanjutnya dibagikan kuisioner pre test terkait dengan materi penyuluhan yang akan disampaikan. Kemudian penyuluhan dimulai dengan pemutaran video kemarahan keluarga korban kasus pembunuhan pasca siding pengadilan. Selesai pemutaran video, penyuluhan disampaikan dengan materi Visum et Repertum, serta di ikuti dialog/diskusi, terakhir dilakukan pembagian kuisioner pos test terkait dengan materi penyuluhan yang telah disampaikan. Kegiatan ini dilakukan selama 1 hari pada mingu kedua.

Pada penutupan panitia mengucapkan terima kasih kepada kepala UPT PUSKESMAS Medan Denai beserta jajarannya sebagai sasaran penyuluhan, diikuti dengan foto bersama tim penyuluhan dengan pejabat UPT PUSKESMAS Medan Denai beserta jajarannya serta berpamitan dengan kepala UPT PUSKESMAS Medan Denai beserta jajarannya.sembari meninggalkan ruang pertemuan. Setelah menyelesaikan kegiatan, peneliti membuat laporan kegiatan pengabdian masyarakat, melakukan publikasi melalui media social dan media massa, kemudian melaporkan hasil kegiatan ke lembaga pengabdian masyarakan USU.

\section{HASIL KEGIATAN}

Berdasarkan wawancara, tanya jawab, pengamatan serta hasil pre- test (nilai ratarata 60,13), dan pos-test (nilai rata-rata 80,92), selama kegiatan berlangsung, kegiatan pengabdian masyarakat ini menunjukkan adanya peningkatan pemahaman tenaga kesehatan baik medis maupun paramedic di UPT PUSKESMAS Medan Denai tentang struktur visum et repertum dan meningkatnya pemahaman tenaga kesehatan baik medis maupun paramedic di UPT PUSKESMAS Medan 
Denai mengenai fungsi dan peran visum et repertum korban tindak pidana .

Beberapa faktor yang mendukung
terlaksananya kegiatan
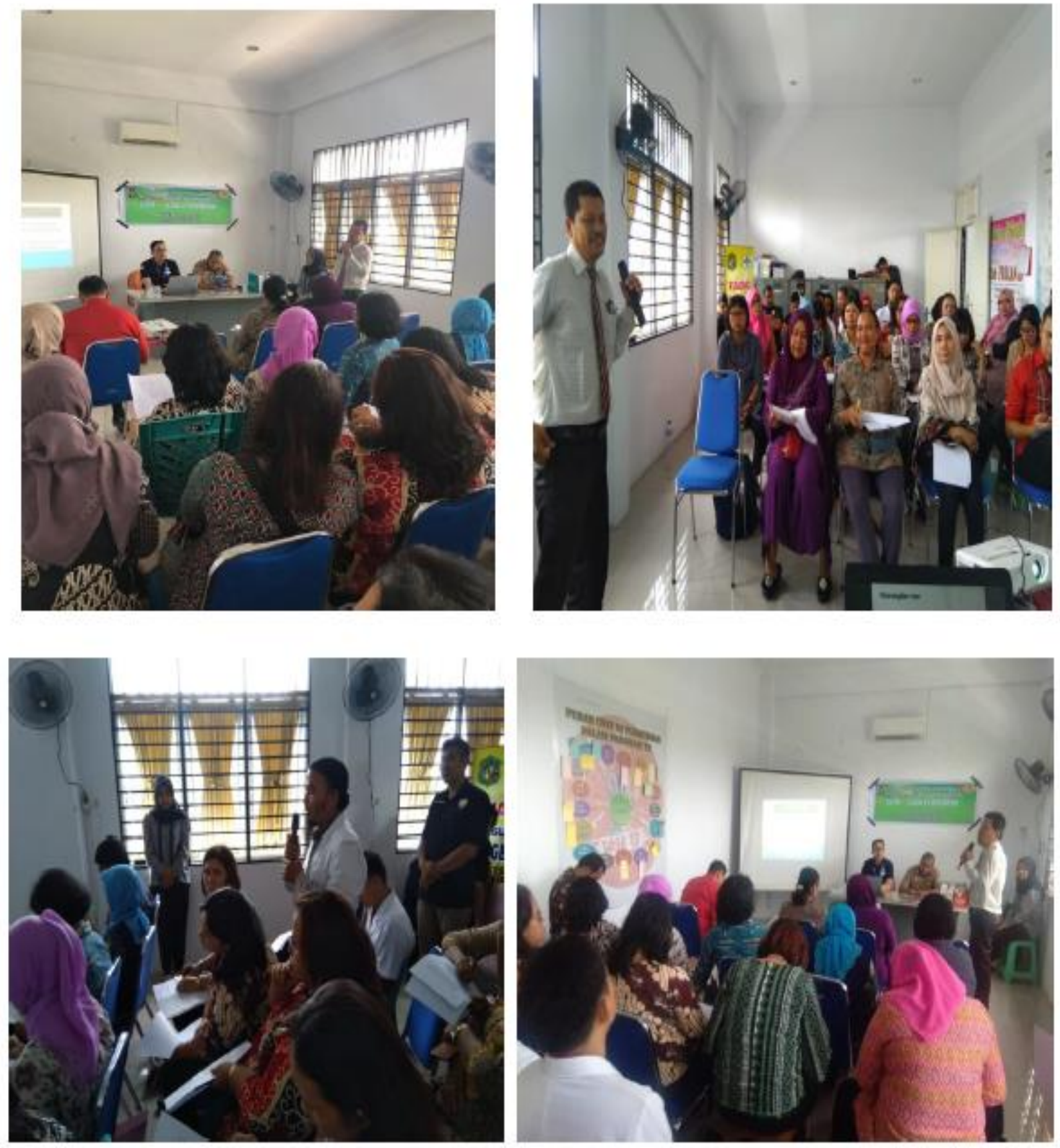

Gambar 1 Tim memberikan materi dalam Penyuluhan Kesehatan Bidang Forensik dengan Topik Visum et Repertum di UPT PUSKESMAS Medan Denai 


\section{SIMPULAN DAN SARAN}

Visum et repertum sebagi salah satu alat bukti yang syah di pengadilan yang berperan dalam proses pembuktian suatu perkara, sehingga tindak pidana yang terjadi semakin jelas maka visum et repertum yang dibuat berdasarkan hasil pemeriksaan dokter harus berkualitas baik .dengan demikian fungsi dan peran visum et repertum itu sendiri terpenuhi, namun berdasarkan beberapa penelitian terhadap visum et repertum kualitasnya belum baik. Berkaitan dengan hal ini, kegiatan penyuluhan ini dilakukan dengan tujuan dapat memberikan pengetahuan tentang undang-undang yang terkait dengan peran dokter umum di UPT PUSKESMAS Medan Denai yang sering kali diminta untuk membantu penyidik dalam membantu penyidikan terkait dengan kasus tindak pidana yang dialami oleh pasien/korban semakin lebih baik serta meningkatkan keterampilan dokter umum di UPT PUSKESMAS Medan Denai yang diminta untuk melakukan pemeriksaan kedokteran serta membuat laporan dalam bentuk visum et repertum dengan kualitas baik. Dari kegiatan pengabdian pada masyarakat ini dapat disimpulkan bahwa pemahaman tenaga kesehatan baik medis maupun paramedic di UPT PUSKESMAS Medan Denai tentang struktur visum et repertum meningkat, serta pemahaman tentang fungsi dan peran dari visum et repertum meningkat. Saran yang dapat diberikan adalah untuk tetap melakukan pelatihan untuk dapat membuat visum et repentum yang baik.

\section{DAFTAR PUSTAKA}

Amir A, : Kapita Selekta Kedokteran Forensik, FK-USU, Medan;1995:pp.5762.

Chadha P.V, : Ilmu Forensik dan Toksikologi , Alih bahasa Johan Hutauruk, Widya Medika, Jakarta;1975:pp.

Hamdani N, : Ilmu Kedokteran Kehakiman, Edisi Kedua, PT. Gramedia Pustaka Utama, Jakarta;1992:p.44-7.

Idries AM, : Pedoman Ilmu Kedokteran Forensic, Edisi Pertama, PT. Binarupa Aksara, Jakarta, 1989, pp.254 - 6 .

Knight B, Arnold, : Simsons Forensic Medicine, 11th Edition, Oxford university Press. Inc, New York - USA;1997:p.19.

Modi NJ, : Medical Jurisprudence and Toksikologi, 18 th Edition, Bombay India, 1972, pp.88-90.

Nandy A, : Principles of Forensic Medicine, New General Book Agency (P) Ltd, Calcuta - India;1995:p.184.

Parikh C.K, : Parikhs textbook of Medical Jurisprudence and Toxicology, Medical Publication, Bombay - India;1979:pp.126-8. 